\title{
Prequalification criteria, according to the government procurement and supplies management Act, B.E. 2560 (2017): branch/type, class, right to bid, ability to carry out
}

\author{
Boonruk Vanborsel ${ }^{1, *}$, and Kumpon Subsomboon ${ }^{1}$ \\ ${ }^{1}$ Civil Engineering Department, Faculty of Engineering, Naresuan University, Phitsanulok, Thailand
}

\begin{abstract}
The objective of this article is to study new bidding prequalification criteria of the Royal Thai government sectors according to the Government Procurement and Supplies Management Act, B.E. 2560 (2017) and compare with the seven government agencies according to Regulations on Procurement, 1992 by emphasizing branch/type of construction, class of the construction entrepreneur/contractor, right to bid per one contract, and number of project to carry out on concurrent time. Content analysis was used in this research, by studying and analysing the prequalification criteria of the Government Procurement and Supplies Management Act, B.E. 2560 (2017) comparing to Regulations on Procurement, 1992 The findings of prequalification criteria concluded that Act, 2017 defined 7 branches/types of construction for construction entrepreneur whereas building construction, road maintenance, and traffic safety were repealed. The right to bid per one contract volume lower than 5 million baht are allowed. There is no limit for the number of project and total project value on concurrent period comparing with Regulations, 1992.
\end{abstract}

\section{Introduction}

In the past decade, a contracting for works of Thai government generally, carried out according to Regulations of the Office of the Prime Minister on Procurement B.E. 2535 (Regulations, 1992) that applied to government agencies, while Regulations of the Ministry of Interior's on procurement of Local Government Administration B.E. 2535 (Regulations, 1992) applied only government body established under the law on local administration. The significant principal as regards the procurement, that is procurement officer of each step of procurement must perform by openness, transparency and giving an opportunity to have fair price competition. Consideration will be given to bidders' qualification and capability and specified that any government agency or local administration organization who requires making a pre-qualification for contracting for works can be performed only in the case which necessitates limiting for the qualified bidders. Contractor prequalification is the most effective way to support client's decision in order to select contractors from the short list of qualified contractors [1]. Selecting the right contractor for the right project is the most crucial challenge for any construction client [2], however contracting for works of government construction projects had many problems: like, co-interest bidder, action impeding fair and free competition, corruption, and, moreover the important agencies for example; local administration organization, office of the basic education commission, and so on did not make a list of prequalified bidder. As a result, bidding process occasionally got unqualified, lack of capacity, and availability contractor to carry out constructions. It leads to construction delay, low quality, and abandonment of construction projects. In 2017, procurement in Thai government had a big change: by repealing all of the traditional Regulations, 1992 and enforce "Government Procurement and Supplies Management Act, B.E 2560" (Act, 2017) [3] for all government sector using same standard framework, transparency/disclosure, accountability, fairness competition, and value for money. For this reason, this article aims to study prequalification criteria of Thai government sector according to the new Act, 2017 and compare with seven government agencies which make a list of pre-qualified bidder according to the traditional Regulations, 1992 by emphasizing branch/type of construction, /class of the construction entrepreneur/contractor, right to bid per one contract, and the number of projects to carry out on concurrent time.

\section{Methodology}

Contents analysis was used in this research to study and analyze the prequalification criteria of (1) Thai government sector which make a list of construction entrepreneur according to Act, 2017 and (2) the seven government agencies: Department of Public Works and Town Planning (DPW\&TP), Department of Highways

* Corresponding author: boonruk vanborsel $(a$,yahoo.com 
(DOH), Department of Rural Roads (DRR), Marine Department (MD), Bangkok Metropolitan Administration (BMA), Royal Irrigation Department (RID), and Department of Water Resources (DWR); which make a list of pre-qualified bidder according to the Regulations, 1992 by emphasizing branch/type of construction, class of the construction entrepreneur/contractor, right to bid per one contract, and the number of projects that ability to carry out on concurrent time. As a result of content analysis, the differences of prequalification criteria between Act, 2017 and Regulations, 1992 were compared.

\section{Results}

\subsection{Branch/Type of construction}

Table 1 shows Act, 2017 defined branch of construction that should make a list of construction entrepreneur for all government sector were specified into 7 branches: (1) road construction and special class, (2) bridge construction and tunnel/underpass construction and special class, (3) irrigation construction, (4) bank protection and coastal construction, (5) construction of structure in the sea, (6) dredging, and maintenance of coastal waterways construction, and (7) dredging, and maintenance of domestic water channels construction. While the seven government agencies which make a list of pre-qualified bidder according to the Regulations, 1992 defined branch of construction were (1) Department of Highways (DOH) divided construction into four types: road construction, bridge construction, roads maintenance and traffic safety, and special class construction, (2) Department of Rural Roads (DRR) divided construction into three types: road construction bridge construction and tunnel or underpass, road maintenance work, and traffic safety, (3) Marine Department (MD) divided construction into three types: bank protection construction and coastal protection wall construction, dredging and maintenance of domestic water channels, and dredging and maintenance of coastal waterways, (4) Royal Irrigation Department (RID) divided irrigation construction into four types: headwork structure and/or appurtenant structure, delivery system and/or appurtenant structure, drainage system and/or appurtenant structure, land consolidation and/or on-farm development, (5) Department of Water Resources (DWR) divided work of water resource conservation, rehabilitation and development into four types: headwork structure, delivery/ diversion/ distribution system, drainage system, work of water resource improvement rehabilitation, (6) Department of Public Works and Town Planning (DPW\&TP) divided construction into 8 types: building, dam, drainage channel, wastewater treatment plant, flood prevention, road, bridge, and landscape improvement work, and (7) Bangkok Metropolitan Administration (BMA) divided construction into two types: buildings and road work.

Table 1. Comparison of branch/type of construction between all government sector which make a list of construction entrepreneur according to Act, 2017 and the seven government agencies which make a list of pre-qualified bidder according to Regulations, 1992

\begin{tabular}{|c|c|c|c|c|c|c|c|c|}
\hline \multirow{2}{*}{$\begin{array}{l}\text { Branch/type of construction } \\
\text { (Based on Regulations, 1992) }\end{array}$} & \multirow{2}{*}{$\begin{array}{c}\text { Act, } 2017 \\
\text { Government } \\
\text { sector (all) }\end{array}$} & \multicolumn{7}{|c|}{ Regulations, 1992} \\
\hline & & $\begin{array}{l}\text { DPW } \\
\text { \&TP }\end{array}$ & DOH & MD & BMA & DRR & RID & DWR \\
\hline \multicolumn{9}{|l|}{1 Building construction } \\
\hline 1.1 Building construction, and other relations & No & Yes & No & No & Yes & No & No & No \\
\hline \multicolumn{9}{|l|}{2 Road, bridge, and box culvert construction } \\
\hline 2.1 Road construction & Yes (1) & Yes & Yes & No & Yes & Yes & No & No \\
\hline 2.2 Bridge construction & Yes (2) & Yes & Yes & No & Yes & Yes & No & No \\
\hline 2.3 Tunnel/underpass construction & Yes (2) & Yes & Yes & No & Yes & Yes & No & No \\
\hline 2.4 Road maintenance & No & Yes & Yes & No & Yes & Yes & No & No \\
\hline 2.5 Traffic safety & No & Yes & Yes & No & Yes & Yes & No & No \\
\hline 2.6 Road/bridge construction (special class) & Yes (1) (2) & No & Yes & No & No & No & No & No \\
\hline \multicolumn{9}{|l|}{3 Irrigation construction } \\
\hline 3.1 Headwork structure and/or appurtenant structure & Yes (3) & Yes & No & No & Yes & No & Yes & Yes \\
\hline 3.2 Delivery system and/or appurtenant structure & Yes (3) & No & No & No & No & No & Yes & Yes \\
\hline 3.3 Drainage system and/or appurtenant structure & Yes (3) & Yes & No & No & Yes & No & Yes & Yes \\
\hline 3.4 Land consolidation and/or on-farm development & Yes (3) & No & No & No & No & No & Yes & No \\
\hline 3.5 Water resource improvement rehabilitation & Yes (3) & No & No & No & No & No & No & Yes \\
\hline 3.6 Flood protection & Yes (3) & Yes & No & No & No & No & No & No \\
\hline \multicolumn{9}{|l|}{4 Other construction } \\
\hline 4.1 Construction of structure in the sea & Yes $(5)$ & No & No & No & No & No & No & No \\
\hline $\begin{array}{l}\text { 4.2 Bank protection construction, and coastal protection } \\
\text { wall construction }\end{array}$ & Yes (4) & Yes & No & Yes & Yes & No & No & No \\
\hline 4.3 Dredging, and maintenance of coastal waterways & Yes (6) & No & No & Yes & No & No & No & No \\
\hline $\begin{array}{l}\text { 4.4 Dredging, and maintenance of domestic water } \\
\text { channels }\end{array}$ & Yes (7) & No & No & Yes & Yes & No & No & No \\
\hline
\end{tabular}


Table 2. Right to bid per one contract, (baht) subjected to class of construction entrepreneur and branch/type of construction according to Act, 2017

\begin{tabular}{|c|c|c|c|c|c|c|c|}
\hline Class & $\begin{array}{c}\text { Road } \\
\text { construction }\end{array}$ & Bridge construction & $\begin{array}{c}\text { Irrigation } \\
\text { construction }\end{array}$ & $\begin{array}{c}\text { Bank } \\
\text { protection } \\
\text { and coastal } \\
\text { construction } \\
\end{array}$ & $\begin{array}{l}\text { Construction } \\
\text { in the sea }\end{array}$ & $\begin{array}{c}\text { Dredging, and } \\
\text { maintenance of } \\
\text { coastal } \\
\text { waterways } \\
\end{array}$ & $\begin{array}{c}\text { Dredging, and } \\
\text { maintenance of } \\
\text { domestic water } \\
\text { channels } \\
\end{array}$ \\
\hline Special & Unlimited & Unlimited & Unlimited & Unlimited & Unlimited & Unlimited & Unlimited \\
\hline 1 & $<500 \mathrm{M}$ & Type 1-4, unlimited & $<1,000 \mathrm{M}$ & $<150 \mathrm{M}$ & $<150 \mathrm{M}$ & $<80 \mathrm{M}$ & $<40 \mathrm{M}$ \\
\hline 2 & $<300 \mathrm{M}$ & Type 2-4, unlimited & $<500 \mathrm{M}$ & $<100 \mathrm{M}$ & $<80 \mathrm{M}$ & $<40 \mathrm{M}$ & $<20 \mathrm{M}$ \\
\hline 3 & $<150 \mathrm{M}$ & Type 3-4, unlimited & $<300 \mathrm{M}$ & $<60 \mathrm{M}$ & $<30 \mathrm{M}$ & $<20 \mathrm{M}$ & $\geq 5 \&<10 \mathrm{M}$ \\
\hline 4 & $<60 \mathrm{M}$ & Type 4, unlimited & $<100 \mathrm{M}$ & $<30 \mathrm{M}$ & $<15 \mathrm{M}$ & $\geq 5 \&<10 \mathrm{M}$ & - \\
\hline 5 & $<20 \mathrm{M}$ & Type $4, \geq 5 \&<10 \mathrm{M}$ & $<25 \mathrm{M}$ & $\geq 5 \&<10 \mathrm{M}$ & $\geq 5 \&<10 \mathrm{M}$ & - & - \\
\hline 6 & $\geq 5 \&<10 \mathrm{M}$ & - & $\geq 5 \&<10 \mathrm{M}$ & - & - & - & - \\
\hline
\end{tabular}

Table 3. Right to bid per one contract (baht) subjected to class of contractor and branch/type of construction according to Regulations, 1992

\begin{tabular}{|c|c|c|c|c|c|c|}
\hline \multirow{3}{*}{ Class } & \multirow{3}{*}{$\begin{array}{c}\text { DPW\&TP } \\
\text { Construction }\end{array}$} & \multicolumn{2}{|l|}{ DOH } & \multicolumn{3}{|c|}{ MD } \\
\hline & & \multirow[b]{2}{*}{ Road } & \multirow[b]{2}{*}{ Bridge } & \multirow{2}{*}{$\begin{array}{l}\text { Bank protection and } \\
\text { coastal protection wall }\end{array}$} & \multicolumn{2}{|c|}{ Dredging and maintenance } \\
\hline & & & & & $\begin{array}{c}\text { Coastal } \\
\text { waterways }\end{array}$ & $\begin{array}{c}\text { Domestic water } \\
\text { channels }\end{array}$ \\
\hline Special,A & Unlimited & - & - & - & - & - \\
\hline Special & $<150$ & Unlimited & Unlimited & Unlimited & - & - \\
\hline 1 & $<100 \mathrm{M}$ & Standard $1-5$, special $;<500 \mathrm{M}$ & Type $1-4$ & $<100 \mathrm{M}$ & Unlimited & Unlimited \\
\hline 2 & $<60 \mathrm{M}$ & Standard $1-5$, special $;<300 \mathrm{M}$ & Type 2-4 & $<60 \mathrm{M}$ & $<80 \mathrm{M}$ & $<60 \mathrm{M}$ \\
\hline 3 & $<30 \mathrm{M}$ & Standard $1-5 ;<150 \mathrm{M}$ & Type 3-4 & $<30 \mathrm{M}$ & $<40 \mathrm{M}$ & $<30 \mathrm{M}$ \\
\hline 4 & $<10 \mathrm{M}$ & Standard $3-5 ;<6 \mathrm{M}$ & Type 4 & $<10 \mathrm{M}$ & $<20 \mathrm{M}$ & $<10 \mathrm{M}$ \\
\hline
\end{tabular}

Table 3. (Cont.) Right to bid per one contract (baht) subjected to class of contractor and branch/type of construction according to Regulations, 1992

\begin{tabular}{|c|c|c|c|c|c|c|c|}
\hline \multirow[b]{2}{*}{ Class } & \multicolumn{2}{|c|}{ BMA } & \multicolumn{3}{|c|}{ DRR } & \multirow{2}{*}{$\begin{array}{c}\text { RID } \\
\text { Irrigation }\end{array}$} & \multirow{2}{*}{$\begin{array}{c}\text { DWR } \\
\begin{array}{c}\text { Water resource conservation, } \\
\text { rehabilitation and } \\
\text { development }\end{array} \\
\end{array}$} \\
\hline & Road & Buildings & Road & Bridge & $\begin{array}{c}\text { tunnel or } \\
\text { underpass }\end{array}$ & & \\
\hline Special & - & - & Unlimited & Unlimited & Unlimited & Unlimited & - \\
\hline 1 & Unlimited & Unlimited & $<150 \mathrm{M}$ & $<80 \mathrm{M}$ & $<150 \mathrm{M}$ & $<1,000 \mathrm{M}$ & $<500 \mathrm{M}$ \\
\hline 2 & $<60 \mathrm{M}$ & $<50 \mathrm{M}$ & $<60 \mathrm{M}$ & $<40 \mathrm{M}$ & $<60 \mathrm{M}$ & $<500 \mathrm{M}$ & $<100 \mathrm{M}$ \\
\hline 3 & $<30 \mathrm{M}$ & $<20 \mathrm{M}$ & $<20 \mathrm{M}$ & $<20 \mathrm{M}$ & - & $<100 \mathrm{M}$ & $<50 \mathrm{M}$ \\
\hline 4 & $<5 \mathrm{M}$ & $<5 \mathrm{M}$ & $<10 \mathrm{M}$ & $<50 \mathrm{M}$ & - & $>10<25 \mathrm{M}$ & $<10 \mathrm{M}$ \\
\hline
\end{tabular}

Table 4. Comparison of number of projects (nos.) or total project value (baht) that ability to carry out on concurrent time between all government sector according to Act, 2017 and the seven agencies according to Regulations, 1992

\begin{tabular}{|c|c|c|c|c|c|c|c|}
\hline \multirow{3}{*}{ Class } & \multirow{3}{*}{$\begin{array}{l}\begin{array}{c}\text { Government } \\
\text { sector (all) }\end{array} \\
\begin{array}{c}\text { Construction } \\
\text { (7 branches) }\end{array}\end{array}$} & \multirow{3}{*}{$\begin{array}{c}\text { DPW\&TP } \\
\begin{array}{c}\text { Construction } \\
\text { (8 types) }\end{array}\end{array}$} & \multirow{2}{*}{\multicolumn{2}{|c|}{ DOH }} & \multicolumn{3}{|c|}{ MD } \\
\hline & & & & & \multirow{2}{*}{$\begin{array}{c}\text { Bank protection } \\
\text { and coastal } \\
\text { protection wall }\end{array}$} & \multicolumn{2}{|c|}{ Dredging and maintenance } \\
\hline & & & Road & Bridge & & $\begin{array}{c}\text { Coastal } \\
\text { waterways }\end{array}$ & $\begin{array}{c}\text { Domestic water } \\
\text { channels }\end{array}$ \\
\hline Special, A & - & $<2,500$ & - & - & - & - & - \\
\hline Special & Unspecified & $<1,500$ & $6,(4)$ & unlimited & 10 nos. & - & - \\
\hline 1 & Unspecified & $<500$ & 3 & Type $1-4 ;<3$ nos. & 5 nos. & 3 nos. & 3 nos. \\
\hline 2 & Unspecified & $<300$ & 2 & Type $2-4 ;<2$ nos. & 5 nos. & 3 nos. & 3 nos. \\
\hline 3 & Unspecified & $<90$ & 2 & Type $3-4 ;<2$ nos. & 5 nos. & 3 nos. & 3 nos. \\
\hline 4 & Unspecified & $<50$ & 2 & Type $4 ;<2$ nos. & 5 nos. & 3 nos. & 3 nos. \\
\hline 5 & Unspecified & - & - & - & - & - & - \\
\hline 6 & Unspecified & - & - & - & - & - & - \\
\hline
\end{tabular}


Table 4. (Cont.) Comparison of number of projects (nos.) or total project value (baht) that ability to carry out on concurrent time between all government sector according to Act, 2017 and seven agencies according to Regulations, 1992

\begin{tabular}{|c|c|c|c|c|c|c|c|}
\hline \multirow[b]{2}{*}{ Class } & \multicolumn{2}{|c|}{ BMA } & \multicolumn{3}{|c|}{ DRR } & \multirow{2}{*}{$\begin{array}{c}\text { RID } \\
\text { Irrigation }\end{array}$} & \multirow{2}{*}{$\begin{array}{c}\text { DWR } \\
\text { Water resource conservation, } \\
\text { rehabilitation and development }\end{array}$} \\
\hline & Road & Buildings & Road & Bridge & $\begin{array}{l}\text { Tunnel or } \\
\text { underpass }\end{array}$ & & \\
\hline Special & - & - & Unspecified & Unspecified & Unspecified & Unspecified & - \\
\hline 1 & \multirow{4}{*}{$\begin{array}{l}\text { Depend on } \\
\text { performance }\end{array}$} & \multirow{4}{*}{$\begin{array}{l}\text { Depend on } \\
\text { performance }\end{array}$} & Unspecified & Unspecified & Unspecified & Unspecified & Unspecified \\
\hline 2 & & & Unspecified & Unspecified & Unspecified & Unspecified & Unspecified \\
\hline 3 & & & Unspecified & Unspecified & - & Unspecified & Unspecified \\
\hline 4 & & & Unspecified & Unspecified & - & Unspecified & Unspecified \\
\hline
\end{tabular}

\subsection{Class of construction entrepreneur /contractor and right to bid per one contract}

Table 2 (right to bid per one contract subjected to class of construction entrepreneur and branch of construction follow Act, 2017) for (1) road construction, (2) bridge construction, (3) irrigation construction, (4) bank protection and coastal construction, (5) construction of structure in the sea, (6) dredging, and maintenance of coastal waterways construction, and (7) dredging, and maintenance of domestic water channels construction has divided contractors into 7, 6, 7, 5, 5, 4, and 3 classes respectively. All lowest class of construction entrepreneur have the right to bid per one contract $\geq 5$ and $<10$ million baht, while all special classes are unlimited for the right to bid.

Table 3 (right to bid per one contract subjected to class of contractor and branch of construction follow Regulations, 1992) for DOH, DRR (except tunnel or underpass construction), and MD (only bank protection construction, and coastal protection wall construction) has divided contractors into 5 classes. DPW\&TP has divided contractors into 6 classes. The lowest class of all was BMA which has the right to bid per one contract not exceeding 5 million baht.

\subsection{Number of project (nos.) or total project value (baht) to carry out on concurrent time}

Table 4 showing the construction of 7 branches of all government sector according to Act, 2017 did not specify these issues. Whereas class 4 of $\mathrm{DOH}$ would be able to construct maximum 2 projects. All class of MD would be able to construct maximum 5 projects but depend on project value of each class. Class 4 of DPW\&TP could carry out total project value not exceeding 50 million baht. BMA could carry out the projects depend on contractor performance. DRR, RID, and DWR did not specify these issues.

\section{Conclusion}

Prequalification criteria of Thai government sector which make a list of construction entrepreneur according to Act, 2017 are shown as follows:
Act, 2017 compiled definition of construction from seven government agencies which make a list of prequalified bidder according to Regulations, 1992, and defined the branch of construction into 7 branches: road construction, bridge construction, irrigation construction, bank protection and coastal construction, construction of structure in the sea, dredging, and maintenance of coastal waterways construction, and dredging, and maintenance of domestic water channels construction. The building construction, road maintenance, and traffic safety were repealed from the up-to-date Act, 2017.

\subsection{Class of construction entrepreneur /contractor and right to bid per one contract}

All lowest class according to Act, 2017 had the right to bid per one contract volume $\geq 5$ and $<10$ million baht. While all seven government agencies based on Regulations, 1992 except RID had the right to bid per one contract lower than 5 million baht. These are the interest data, why it did not define the right to bid per one contract lower than five million baht.

\subsection{Number of project to carry out on concurrent time}

The finding on these issues showed that all government sector did not specify the number of projects or total project value that construction entrepreneur has the ability to carry out on concurrent time according to Act, 2017.

\section{References}

1. F. Kog, H. Yaman, ECAM 23, 6 (2016)

2. J.R.S. Cristóbal, J Constr Eng Manage. 138, 6 (2012)

3. Royal Gazette, http://www.chiangmailocal.go.th/web master/20171207_0023-5-1349.pdf [In Th ai]. 23 November, URL (accessed: 24.12.2017) (2017)

\subsection{Branch/Type of construction}

